\title{
MULTINATIONAL ENTERPRISES - AN INCREASING IMPORTANCE OF STATE OWNED MULTINATIONAL ENTERPRISES IN THE WORLD ECONOMY
}

\section{${ }^{a}$ MAREK ARENDARČÍK MÚČKA}

Dell Halle GmbH, Raffinerie Str.28, 06112, Halle (Saale) Germany

email: ${ }^{a}$ marek.a.mucka@gmail.com

Abstract: Our paper focuses on the description of both multinational enterprises (MNE) and the state owned multinational enterprises (SO-MNE) rates of importance within the world economy. The impact of the public administration is felt in both counts. Along Europe it is more intensive in the post-communist countries like in Czech Republic and Slovak Republic and the same in some Arab countries where the SO-MNE are intensive even dominantly operating mostly within the energy industry segments.

Keywords: multinational enterprises (MNE), state-owned multinational enterprises (SO-MNE), foreign direct investments (FDI), internationalization

\section{Multinational enterprises (MNE)}

Mudambi (2008) defines MNE as the net of the activities connected through the knowledge and the flow of the products. By Dunning and Lundan (2008) MNE is defined as an international or a transnational enterprise engaging in FDI and owning or controlling the added value activities in several countries. The MNE is characterized by two features: 1 . it enters, organizes and coordinates multiple added value activities within the home market; 2. it internalizes at least some cross border markets regarding the intermediate products resulting from these activities. According to Kusluvan (2013) MNE is defined as the company owning more than $10 \%$ of the assets and operating in the contracting relations like the managerial contracts, franchising and leasing agreements within more than one country. As per Zvirgzde (2013) the selection of the location is of a strategic importance for MNE due to the factors attracting the foreign companies to specific locations and determining the MNE competitiveness from the long-term aspect. According to Baziki and Norbäck (2016) in principle the MNE are the firms characterized by the international advantages like the patents, know-how and the brand name image. These firms are often very big, organizationally established like the companies with limited liability and operating on the stock market. An UNCTAD (2015) paper points out the plan of the MNE to expand their activities in particular through the foreign trade and export within the midterm horizon. Among the preferred entering of the foreign markets the importance of the cross border fusions and acquisitions is in increase. According to UNCTAD (2016) the larger is the MNE the higher is the complexity of its internal ownership relations. The literature shows various criteria regarding the evaluation of the level or multinational intensity or transnationality of the firm; i.) Number and extent of the foreign subsidiaries or affiliated firms owned or controlled by it; ii.) Number of countries where it owns or by some way controls the value added activities like: the mines, plantations, factories, premises, banks, offices and hotels, iii.) Their global assets rate, income, sales, number of the foreign subsidiaries employees iv.) International level of management and ownership, v.) Scope of the internationalization of the higher added value activities like the research and the development. Inter alia - the criteria of measurement intends to cover the quality or the scope of the foreign production and the foreign subsidiaries contribution to the approach or the direct creation of new knowledge, vi.) Scope and the scheme of the systematic advantages resulting from its processing and its impact on the economic activities network within various countries, vii.) Scope where the responsibility for establishment and operation of the company as well as the decision process considering the financial and marketing matters are transferring to the foreign subsidiaries (Dunning, Lundan, 2008, p.3). In general we may say that the professionals tried either to quantify the value of the foreign firm production (eventually its foreign representation) or to identify the rate of the management relationships, organizational processes, operational strategies and the calculation of the production in the manner showing their international or domestic orientations.
(Dunning, Lundan, 2008, p.765, 766). The UNCTAD (2016) statistics acknowledge a MNEs enormous force within the country economy and its positions and importance within the world economy and its constant expansion. The most of the MNE companies are coming from the countries of mature markets while the most MNE affiliations are located in the developing countries.

Table 1: The world's top 100 non-financial MNEs, ranked by foreign assets, 2015

\begin{tabular}{|c|c|c|c|c|}
\hline rank & TNI & Corporation & $\begin{array}{c}\text { Home } \\
\text { economy }\end{array}$ & Industry \\
\hline 1 & 37 & $\begin{array}{c}\text { Royal Dutch Shell } \\
\text { plc }\end{array}$ & $\begin{array}{c}\text { United } \\
\text { Kingdom }\end{array}$ & $\begin{array}{c}\text { Mining, quarrying and } \\
\text { petroleum }\end{array}$ \\
\hline 2 & 64 & $\begin{array}{c}\text { Toyota Motor } \\
\text { Corporation }\end{array}$ & Japan & Motor Vehicles \\
\hline 3 & 67 & $\begin{array}{c}\text { General Electric } \\
\text { Co }\end{array}$ & $\begin{array}{c}\text { United } \\
\text { States }\end{array}$ & $\begin{array}{c}\text { Industrial and } \\
\text { Commercial } \\
\text { Machinery }\end{array}$ \\
\hline 4 & 19 & Total SA & France & $\begin{array}{c}\text { Petroleum Refining } \\
\text { and Related Industries }\end{array}$ \\
\hline 5 & 40 & BP plc & $\begin{array}{c}\text { United } \\
\text { Kingdom }\end{array}$ & $\begin{array}{c}\text { Petroleum Refining } \\
\text { and Related Industries }\end{array}$ \\
\hline 6 & 59 & $\begin{array}{c}\text { Exxon Mobil } \\
\text { Corporation }\end{array}$ & $\begin{array}{c}\text { United } \\
\text { States }\end{array}$ & $\begin{array}{c}\text { Petroleum Refining } \\
\text { and Related Industries }\end{array}$ \\
\hline 7 & 75 & $\begin{array}{c}\text { Chevron } \\
\text { Corporation }\end{array}$ & $\begin{array}{c}\text { United } \\
\text { States }\end{array}$ & $\begin{array}{c}\text { Petroleum Refining } \\
\text { and Related Industries }\end{array}$ \\
\hline 8 & 61 & $\begin{array}{c}\text { Volkswagen } \\
\text { Group }\end{array}$ & Germany & Motor Vehicles \\
\hline 9 & 18 & $\begin{array}{c}\text { Vodafone Group } \\
\text { Plc }\end{array}$ & $\begin{array}{c}\text { United } \\
\text { Kingdom }\end{array}$ & Telecommunications \\
\hline 10 & 65 & $\begin{array}{c}\text { Apple Computer } \\
\text { Inc. }\end{array}$ & $\begin{array}{c}\text { United } \\
\text { States }\end{array}$ & Computer Equipment \\
\hline
\end{tabular}

Source: UNCTAD (2016) World invest report 2015,Annex table 24. The world's top 100 non-financial MNEs, ranked by foreign assets, 2015. Preliminary results based on data from the companies' financial reporting; corresponds to the financial year from 1 April 2015 to 31 March 2016, TNI, the Transnationality Index, is calculated as the average of the following three ratios: foreign assets to total assets, foreign sales to total sales and foreign employment to total employment, c Industry classification for companies follows the United States Standard Industrial Classification as used by the United States Securities and Exchange Commission (SEC), Data refers to 2014, Data in the table are in millions of USD and the number of the employees.

\subsection{State owned multinational enterprises (SO-MNE)}

Jaworek and Kuzel (2015) say that inspite of the fact that the SO-MNE represent the minor part of the total number of MNEs in the world and they have an important portion of foreign subsidiaries and assets regarding their number. According to Kowalsky, Buge, Sztajerowska and Egeland (2013) the fact is that the public sector is long term key economic player within almost all world economies regardless the rate of their development. According to Capobianco and Christiansen (2011) the SO-MNE are achieving a critical position and play an important role as the direct external foreign investors in the time period of two previous decades. UNCTAD (2011) defines the SO-MNE as the enterprises including the parent business firms and its foreign subsidiaries, with the government control interests (full, majority or major minority) if they are not active in the stock market.As the SO-MNE is regarded in particular the state enterprise, public enterprise, public company,governmental business, governmental-tradebusiness or the government owned company. UNCTAD (2014) identified 550 of SO-MNE with foreign assets more than 2 trillions of USD. Sauvant \& Strauss (2012) found that the most of the SO-MNE are originally from the country classified within the developing markets. OECD (2009) defines the SO-MNE as the commercial entity established through either central or local government and under official inspection realized by the government. An OECD (2005) definition of the SO-MNE is regarding it as the government 
owned or the government controlled entities with a corporate form of the assets generating the volume of their income from the goods and service distributions. A SO-MNE is responsible for cca.5\% of the economy of average OECD member country. Predominantly within the countries with ranking on the developing markets this share varies from $10 \%$ to $40 \%$. The exact characteristics of the SO-MNE legal statuses are different within the respective countries. Shapiro and Globerman (2009) emphasize the probability of the state ownership on federal government, state government, government departments or the state retirement funds levels. In spite of $20^{\text {th }}$ century $80^{\text {th }}$ and $90^{\text {th }}$ extensive privatization the state remains a considerable owner of the commercial companies within OECD member and nonmember countries. In some OECD countries the SO-MNE share up to $20 \%$ of GDP, approximately $10 \%$ of employment and more than $40 \%$ of market capitalization. As to the ownership of the SO-MNE within OECD countries the Czech and Slovak Republics are of a high ranking. The state ownership is concentrated within the strategic sectors like the public services, infrastructure, energetics, traffic and telecommunication. Recently and particularly in USA and UK the state ownership within the bank segment undoubtedly increased as the governments of these countries took over the capital shares of the banks and other financial institutions being in crisis. (Shapiro, Globerman, 2009 p.5). Shapiro and Globerman's study demonstrated a probability to make a dividing line between the SO-MNE in mature markets and the SO-MNE in developing and transforming markets. Particularly it is relating to the fact that only a few SO-MNE within mature countries are capable to compete in the global market. Within the mature markets the problems of administration related to the SO-TNC were solved through the combination of the privatization and establishing the corporations. In spite of existing state ownership there is an increased enforce regarding the effective administration. Additionally the remaining commercial SO-TNC within majority of countries are concentrating in several segments being the subject of some form of FDI regulation. On the other hand the SO-TNC in developing and transition markets offer a more complicated reflection. Often the SO-TNC are the part of specific state strategy connected with the national interests and national competitiveness and mostly within the technology and energy segments. Under such conditions a possible failure of the government related to non-commercial purposes, limited transparency and diminished managerial responsibility represent the relevant risks resulting in specific investments of the firms with the consequence of net costs increase to the host economy (Shapiro, Globerman, 2009 p.28). It is highly presumable that the international operations made by the SO-TNC are increasing however it is less presumable that their motivation changes. Henceforth their motivation includes their technology and source accessibility. (Shapiro, Globerman, 2009 p.29). According to Bremmer (2009; Hong et al., 2014) in new era of so called guarded globalization - the effect of FDI state ownership will always be predominant within the segments representing the strategic priorities of participating governments.

Table 2: The top 100 non-financial SO-MNEs from developing and transition economies, ranked by foreign assets, 2014

\begin{tabular}{|c|c|c|c|c|}
\hline rank & TNI & SO-MNE & $\begin{array}{l}\text { Home } \\
\text { economy }\end{array}$ & Industry \\
\hline 1 & 50 & Volkswagen & Germany & Motor vehicles \\
\hline 2 & 70 & Eni & Italy & Petroleum \\
\hline 3 & 67 & Enel & Italy & $\begin{array}{c}\text { Utilities (electricity, gas, } \\
\text { water) }\end{array}$ \\
\hline 4 & 49 & EDF & France & $\begin{array}{c}\text { Utilities (electricity, gas, } \\
\text { water) }\end{array}$ \\
\hline 5 & 40 & GDF & France & $\begin{array}{c}\text { Utilities (electricity, gas, } \\
\text { water) }\end{array}$ \\
\hline 6 & 62 & $\begin{array}{l}\text { Deutsche } \\
\text { Telekom }\end{array}$ & Germany & Telecommunications \\
\hline 7 & 17 & CITIC Group & China & Diversified \\
\hline 8 & 30 & Statoil ASA & Norway & Petroleum \\
\hline 9 & 72 & Airbus Group & France & Aircraft \\
\hline 10 & 42 & General Motors & USA & Motor vehicles \\
\hline
\end{tabular}

Source: UNCTAD (2015) World invest report 2015,Annex table 24. The world's top 100 non-financial SO-MNEs, ranked by foreign assets, 2015. Preliminary results based on data from the companies' financial reporting; corresponds to the financial year from 1 April 2012 to 31 March 2013, TNI, the Transnationality Index, is calculated as the average of the following three ratios: foreign assets to total assets, foreign sales to total sales and foreign employment to total employment. The state is the owner of minimum $10 \%$ share or it is the majority owner in the firms.

2 Multinational enterprises - interactions with public administration

On one hand the state strives to invite the investors especially to the regions of low employment with aim to increase the employment and this way to eliminate the negative impact on the respective municipalities or the entire region. Generally the state supports the domestic and international companies through the grants, contributions and various allowances provided that they decide to realize their business activities in the respective municipality or the region. Moreover the state prepares the development programs and the same it should build up the conditions enabling the secure and transparent business activities with sufficient legal and financial safety. The key criteria is also a predictability of politics and the decisions both positive and negative influencing the enterprise within specific region or the business subject. One of the roles of the state is to provide its citizens with an equitable redistribution of the sources. In a large extent the sources are coming especially from the major MNEs paying the taxes, fees and levies on the territory of this state. Accordingly and in principle the more successfully enterprising subjects the more taxes for the state and the more means redistributing in health service and school system etc. On the other hand the customer rights are regulated by the laws of the state. The state enters the interaction on various levels: a) related to the business subject, b) related to the end user, c) related to the self-governing entity where the business subject is active or its activity is in consideration, d) related to the municipality where the business subject is active or its activity is in consideration. The state and the business subject relationships are the most often known regarding the important MNEs in connection with their investments that may be specified as the strategic investments or the investments of the national interest or the investments of the strategic state interest. According to Bartková (2005) in connection with provided investment motivation it was necessary to define a term strategic investment (SI). Since the authorities of the institutions, qualified to determinate on the investment stimulus, more often use this term and it is not defined what is meaning of the term SI. The economists considered to define SI with various parameters. The MNE must resp. they are obliged to respond to the legislative changes. This change is related to not only one subject but to any subject realizing the business within the respective segment. We can see mutual relationships and interactions existing between the business subjects. We may differentiate between the competitive and cooperative relationships especially regarding establishment of various associations or federations uniting the subjects for the purpose of the communication also with the public administration bodies. In case when by its legal rules the state protects the end user over the scope of the necessity (existence of unreasonably long term for submission of the initiative regarding the replacement of the product with a new one - see DOA process, very strict and short terms for the manufacturers and the service partners regarding the repair of the goods with right of return the total paid sum or to replace the defective goods with new one, and so on|). These cases represent the mutual interest of the business subjects and the same a need of common and coordinated procedures toward the business subject initiating the changes. We may mention an example of the legal lobbing or the initiation of the discussions with authorized public administration bodies for the purpose of making the compromise. In this sense the business subjects are following their interests and are focusing on the fact that the implementation of new legislation will not impact their business negatively regarding the finance. The task of the state is a relevant explanation of the reasons of the legislative changes however the ideal is that the unions of the employers are from time to time concerned with the legislative changes and making 
them a proposal of active cooperation regarding preparation of the changes and a probability to comment it. This way we may avoid the only administrative basis of the decisions on respective changes realized without any knowledge of current issues and without foresight of the consequence toward the business segment or the end users/consumers. The decisions of that type have to be realized by the subject matter experts (SME) in the field and based on consideration and interpretation of the complex situation and the same a necessity or irrelevance of any change. The resolutions should not be made only on political basis even though these may not be absolutely excluded in practice. The relationships among particular business subjects may be understand on various levels: competitive (a standard competitive relation), the level of cooperation in mutual interest (e.g. a cooperation in achieving the legislative regulation or in obtaining some respective requirements or on the level of partners cooperation (manufacturer- retailer, manufacturer logistics company, manufacturer - marketing agency and so on). The business subjects are forming mutual relations and interactions. These are important among the segments too. Another example from IT sector: None of the existing manufacturer is isolated but he joins various mutual relations with: contractors, subcontractors, service partners, auditing agencies, consulting agencies, logistics, telecommunication partners, marketing, and so on. MNE is forming the network of the relationships and bonding within the local background and the MNE operates within international and even in the global rate depending on the rate of the respective expanding corporation. Any of the business subjects makes its efforts to keep the costs as low as possible or to reduce it systematically. It may be reached by the outsourcing too. A split of the operations is by the company outsourced toward the companies specialized within the respective problems. It is an advancement that on the respective market a specialized company has built its entire infrastructure performing required task, disposes a qualified man power, its reputation is good, holds required certifications and concessions and operates its tasks based on prior specified conditions. Let us see in more detail an example of the end user/consumer legal protection regulation. Here we reach even the level of the European Union that within the scope of all countries and uniformly regulates the way of the protection of the end user - consumer. For instance a two year warranty for the consumer products, right to return a product up to 14 days in case when it was purchased via internet or by the phone order, the right to make a claim and ask for both the remedy up to 30 days or the reimbursement. Any above mentioned institution protects the end user/consumer and gives him the specific rights that may be judicially claimed if the business subject is in default. Through its bodies the state operates like the institution defining the basic rules of the game that have to be respected by any player on the market otherwise he takes the risk of a sanction. The sanction may be understood as the sanction of the state toward the business subject not respecting the rules established by law. In addition the sanction concerning the business subject may represent an efflux of the purchasers who will not purchase their goods or services until the business subject changes its way of activity. On the market the end user/consumer will look for another subject meeting its requirements as much as possible and the price will not be the determining criteria every time. If the end user/consumer is overprotected within particular countries then the conflict may occur. In EU it is for instance Netherlands. The end user/consumer, the private person buying the personal computer is by law entitled to two years warranty. However if after expired warranty period the personal computer goes to break and the end user/consumer requires the repair then the costs of the total repair will not be covered only by himself but the specific part shall be covered by the manufacturer or the distributor or by other business subject where the product was purchased. The sum paid by the end user/consumer and the sum paid by the business subject is calculated according to pattern in law. This is one of the business barriers especially within IT segment and in the segment of the consumer electronics in Netherlands. Both the manufacturer and the distributor must negotiate the procedure of furnishing the warranty and non-warranty repairs with adequate prices. In many cases the consequence is the higher price of the final product. Regarding the business subject it may result in the fact that in contrary to the direct business better is to do the business through the distributors as this minimizes its risk. This relationship forms an interesting consumer culture as the consumer is ready to pay the higher price of the product however on the other hand the consumer expects that in case of warranty and non-warranty repair his requirement will be executed quickly and without unnecessary delay and he may be sure of the fast and qualitative state authority bodies decisions. Essentially MNE is interested in the correct relationships with the local administration bodies and the local state administration bodies. It is concerning the mutual relations where any party follows out its own interests and the aims. The interests of MNE are including: the probabilities to gain the access to attractive real estate or to the well accessible premises for the purpose of building up a branch establishment; a probability of lucrative access to man power of the respective profile whether we are talking about the graduates of the respective fields of study at both the universities and the high schools or about the unemployed persons registered by the employment agency; the favourable price for work; alternative to work for much lower costs during public holidays; a weak position of the workers councils; the employer reputation offering the some standard conditions to its employees in comparison to competing business; the flexibility in case of need to reduce the number of employees. The interests of the self-governing unit are including: an attractiveness of the business subject whether finance or non-finance origin through its engagement in existing both business and public life of the region; connection to existing infrastructure; the support of the local home consumptions provided that the employees of the company shall spend their earnings within the region and supporting other local business subjects; the business subject engagement in activities within the region; the support of the respective schools graduates being a long term interest of the business subject. The selfgoverning region as founder of many educational institutions should play an important role in the decisions regarding the fields preferable in graduates' implementation at the labour market. The business subject is an inseparable part of the relations and the interactions within the municipality. The municipality represents also the subject influencing the business subject making its decision regarding its enterprising in specified municipality or not. The municipality remains an important subject regarding the interactions with the public administration bodies even after the business subject is active developing its business activities. Another example may be mentioned regarding the cooperation with the employment agencies, schools and universities in connection with probable sale and hire of the real estate, development of both the municipality and the municipal plan, the accessibility and organization of the public transportation, the support of the municipal activities, the business subject employees volunteer activities etc. Therefore on one hand we see formalized relationships, the taxes, fees, licenses, agreements and on the other hand the informal relationships representing the basis of bilateral cooperation. The informal relationships are including the support of the schools, health care or social institutions, the student grants or direct high school or university grants, municipal culture and sport support etc. We may not forget an important attribute of informal or formal employees association for the purpose of support of various activities or the subjects or the civil corporations. To these we may count also $2 \%$ of tax transferred to the specified subject and the volunteer activities in pre-school and school institutions. The mentioned forms the interactions above the formal scope of the municipality and business subject relationship where the business activity for the purpose of generation of the profit represents the primary aim.

\section{Conclusions}

We summarized the MNE and SO MNE theoretical definitions and we dealt with the interactions between MNE and a host economy. Our aim was to describe and to document various aspects and seen it like the respective unit. The MNE problematic was seen by us from the perspective of the state resp. the public administration, from the perspective of the 
private sector and finally from the perspective of the citizen as the consumer and user of the goods and the services. We assume that our added value is based on the combination of mentioned perspectives and various interests and needs of the respective involved sectors. Our important tools are the modelling and mind map, the brainstorming and description. We illustrated the MNE reaction to the amendment of the legislation of the specific country and the relationships among the business subjects in economy. An example of the amendment of the legislation is based on Domansky general scheme which was applied in the specified process. Our presumption is that the Domansky scheme of MNE interactions in the host economy may be applied to any MNE, country and process. The common features in the sphere of cooperation may be seen especially in the relationships among MNE business partners, and the same on the side of the conflict where the part of it may be the sanction applied by the state in case of failing to respect the new legislation. Moreover it is the inspection carrying out by the authorized courts in enquiring the citizen/end user claims regarding broken customers rights and the common features we see also within the processes that the MNE must continuously update in the way respecting the legal regulations in force. According to the example of the DOA (defective on arrival) process we may describe that MNE are not only the economic involved companies performing the interactions limited to its traditional partners but they are generating also both the contacts and the relations with the state and the state institutions. And last but not least they have to know how to face and to react to the particularity of various economies and the environments related to all the scale of the processes, procedures, respective problems and this all on the side of the inputs and the same on the side of the outputs. Any problem connected with the MNE interactions is regarded from three aspects: from the perspective of the state and MNE and the end user. The public administration is in the interaction with MNE in the scope of the legislative aiming to support the growth of employment by supporting the international and domestic investments through appropriate and particularly competitive tax system. The public administration should provide a long term and stable both political and economic situations in the range preparing the conditions acceptable for business activity in respective country or region and without negative impact on the business sector. Moreover the important attributes are including the stability of the law system and an enforceability of law from the side of MNE and the same from the side of the citizens or the state. We may not forget that toward the end user the state govern also the relations establishing, changing or revoking the rights or the obligations of the respective subjects (among others the business subject or the citizen like the purchaser of the product or the service). From the MNE aspect is a critical perception of above mentioned factors to which may be added the existing infrastructure, local particularities, accessibility and the costs of man power, existence and relevance of the trade unions. Regarding its expansion the MNE decision is based on a complex line of the indicators resulting in positive or negative resolutions. As the important elements we may see also the probabilities to utilize the tax allowances or the tax exemption; probability to obtain the premises or to gain a lucrative rent of the buildings etc. The same the probabilities of specific grants for the purpose of new jobs if the company undertakes to engage the unemployed person long term claiming for work in the labour process. We may not forget the cooperation with the schools, the trade schools and the universities depending on the business subject requirements. The aim is about to be exercising on the labour market. The school should adopt its profiles to the requirements of the market so that to produce not only the graduates but the persons of the attractive profiles capable to exercise them on the labour market. From the aspect of the citizen or the consumer we understand the problem of the relations in two levels: the relationship between the citizen and the state and then the level of the relationship between the citizen and the MNE. The citizen may claim his rights provided him by the law through the authorized bodies, for instance by the administrative or judicial bodies. In particular it concerns the rights granted by the state which is also the protector and a subject providing the inspection of the observation of the rights and its enforceability. The state is an authority competent to sanction the subjects violating the rights or the obligations. Let us look at the example of the consumer rights protection. Regarding the product bought through the internet, the end user/consumer is entitled to return the product up to 14 workdays. If the retailer does not satisfy the claim then the end user may turn to the commercial inspection that will require the revision and in case of finding the inaccurateness it will apply the remedy of the matter or shall grant the sanction.

\section{Literature:}

1. Baziki S. B., Norbäck, P. J., Persson, L., Tag, J. Cross-border Acquisitions and Restructuring: Multinational Enterprises and Private Equity-firms, 2015.

2. Bartkova, D., Efektívnost' investičných stimulov a ich aplikácia v podmienkach SR, 2005 . Retrieved from: http://www3.ekf.tuke.sk/work/Konferencia\%20Herlany/zbornik CD/doc/Bartkova.pdf

3. Beck, U.,What is globalization?. John Wiley \& Sons, 2015.

4. Capobianco, A., Christiansen, H., "Competitive Neutrality and State-Owned Enterprises: Challenges and Policy Options", OECD Corporate Governance Working Papers, No. 1, Paris: OECD Publishing, 2011.

5. Domanski, B., Transnational Corporations and the postsocialist economy: learning the ropes and forging new relationships in contemporary Poland, The networked world Making Sense of Globalization, Routledge, London, 2004

6. Dunning, J., H., Lundan, S., M., Multinational Enterprises and the Global Economy, Second Edition, Edward Elgar Publishing Limited, 2008

7. Hong, J., Wang, C., Kaforous, M.,"The Role of the State in Explaining the Internationalization of Emerging Market Enterprises”, British Journal of Management, Vol. 26, No. 1, pp. 45-62, 2014.

8. Jaworek, M., Kuzel, M., Transnational Corporations in the World Economy: Formation, Development and Present Position. Copernican Journal of Finance \& Accounting, 4(1), 55-70. 2015.

9. Kowalski, P., Buge, M., Sztajerowska, M., Egeland, M." “State-Owned Enterprises: Trade Effects and Policy Implications", OECD Trade Policy Papers, No. 147, Paris: OECD Publishing, 2013.

10. Kusluvan, S., A, Review of Theories of Multinational Enterprises, D.E.Ü.İI.̇..F. Dergisi, Vol. 13, Issue: I, pp.163180, 1998.

11. Mudambi R., Location, control, and innovation in knowledge-intensive industries. Journal of Economic Geography 8 699-725.2008.

12. Oatley, T. International political economy. Routledge, 2015. 13. OECD, "Top Barriers and Drivers to SME Internationalisation", Report by the OECD Working Party on SMEs and Entrepreneurship, OECD, 2009.

14. Sauvant, K., Strauss, J., "State-controlled entities control nearly US\$ 2 trillion inforeign assets", Columbia FDI Perspectives, No. 64, April 2, 2012.

15. Shapiro, D., Globerman, S.,"The International Activities and Impacts of State-Owned Enterprises”, Simon Frasier University, 2009.

16. UNCTAD, World Investment Report 2007: Transnational Corporations, Extractive Industries and development.

17. UNCTAD, Transnational corporations, 2014.

18. UNCTAD, World invest report 2015, top 10 non-financial stated owned MNEs ranked by foreign assets, 2015

19. UNCTAD, World Investment report 2016.

20. Zvirgzde, D., Schiller, D., Diez Revilla, J., Location choices of multinational companies in transition economies: A literature review, Search, 2013.

Primary Paper Section: A

Secondary Paper Section: AE 